\title{
DEVELOPMENT OF MOUSE EGGS FERTILIZED IN VITRO BY EPIDIDYMAL SPERMATOZOA
}

\author{
H. MIYAMOTO AND M. G. GHANG \\ Worcester Foundation for Experimental Biology, \\ Shrewesbury, Massachusetts 01545, U.S.A. \\ (Received 15th October 1971, accepted 11th February 1972)

\begin{abstract}
Summary. About $64 \%$ of 854 superovulated mouse eggs were fertilized in vitro by epididymal spermatozoa and were capable of cleaving in chemically defined media. Approximately $10 \%$ of such eggs fertilized in vitro or in vivo could develop to the blastocyst stage in culture. When two-cell eggs fertilized in vitro and in vivo were transferred to the oviducts of pseudopregnant mice, only $13 \%$ and $16 \%$, respectively, developed into normal fetuses.
\end{abstract}

The possibility of development of mouse eggs fertilized in vitro by spermatozoa recovered from the uterus has been reported by Whittingham (1968), Mukherjee \& Cohen (1970) and Cross \& Brinster (1970). It has also been reported that mouse eggs can be fertilized in vitro by epididymal spermatozoa in the presence of bovine follicular fluid (Iwamatsu \& Chang, 1969, 1970, 1971) or in its absence (Toyoda, Yokoyama \& Hosi, 1971), but whether such eggs can develop in culture and even mature into fetuses following transfer to recipients has not been investigated. This paper reports the results of experiments designed to determine the proportion of mouse eggs fertilized in vitro by epididymal spermatozoa in the absence of bovine follicular fluid, and the proportion of fertilized eggs which developed into blastocysts following further culture. The possibility of normal development following the transfer of such eggs to the oviducts of recipients was also investigated.

Superovulation in mature female Swiss albino mice, weighing 21 to $25 \mathrm{~g}$, was induced by the intraperitoneal injection of 5 i.u. PMSG followed by 5 i.u. HCG 44 to $48 \mathrm{hr}$ later. The mice were killed 14 to $16 \mathrm{hr}$ after the injection of HCG, their oviducts were removed and placed under light paraffin oil (viscosity, 125/135) in a watch-glass kept at $37^{\circ} \mathrm{C}$, and eggs in the cumulus clot were released into the oil. The paraffin oil was previously equilibrated with $5 \% \mathrm{CO}_{2}$ in air in the presence of a small volume of saline.

A sperm suspension was prepared by mincing cauda epididymidis of a mature Swiss albino mouse in a watch-glass containing $1 \mathrm{ml}$ of a medium which was slightly modified, by the addition of $21.58 \mathrm{~mm}$-sodium lactate, to that used by Toyoda et al. (1971). About $0.2 \mathrm{ml}$ sperm suspension was added to the egg clot under the oil. After adding another 0.2 to $0.3 \mathrm{ml}$ medium, the eggs and spermatozoa were thoroughly mixed and then incubated at $37^{\circ} \mathrm{C}$ in an atmos- 
phere of $5 \% \mathrm{CO}_{2}$ and air. The final concentration of spermatozoa in each watch-glass was 1 to $5 \times 10^{3} / \mathrm{mm}^{3}$.

After incubation for 6 to $7 \mathrm{hr}$, the eggs were taken out and washed in $2 \mathrm{ml}$ of a culture medium and then cultured under oil in a small droplet of culture medium of the same composition as that used by Whitten \& Biggers (1968), except that the concentration of sodium pyruvate was $0.55 \mathrm{~mm}$ instead of 0.33 mm. After culture for $24 \mathrm{hr}$, all the eggs were washed twice in the medium, the cleaved eggs were counted and only two-cell eggs were cultured for another 72 $\mathrm{hr}$ in fresh medium. The number of eggs which had developed into morulae or blastocysts were recorded. In some experiments, one-cell eggs fertilized in vivo from mated animals were similarly cultured as controls.

\section{TABLE 1}

DEVELOPMENT OF MOUSE EGGS FERTILIZED in vitro WITH EPIDIDYMAL SPERMATOZOA AND THEN FURTHER GULTURED FOR 24 TO 96 HR

\begin{tabular}{l|c|c|c|c|c}
\hline \multicolumn{1}{c|}{ Eggs } & Exp. & $\begin{array}{c}\text { No. of eggs } \\
\text { cultured }\end{array}$ & $\begin{array}{c}\text { No. of two-cell } \\
\text { eggs obtained } \\
24 \text { hr later } \\
(\%)\end{array}$ & $\begin{array}{c}\text { No. of morulae } \\
\text { obtained } \\
96 \text { hr later } \\
(\%)\end{array}$ & $\begin{array}{c}\text { No. of blastocysts } \\
\text { obtained } \\
96 \text { hr later } \\
(\%)\end{array}$ \\
\hline Fertilized & 1 & 62 & $49(79)$ & $8(16)$ & $4(8)$ \\
in vivo & 2 & 122 & $83(68)$ & $6(7)$ & $13(16)$ \\
& 3 & 80 & $56(70)$ & $4(7)$ & $3(5)$ \\
Total & 4 & 98 & $68(69)$ & $10(15)$ & $2(3)$ \\
\hline Fertilized & 1 & 131 & $78(60)$ & $6(7)$ & $10(13)$ \\
in vitro & 2 & 144 & $72(50)$ & $8(11)$ & $6(8)$ \\
& 3 & 89 & $56(63)$ & $3(5)$ & $7(13)$ \\
& 4 & 140 & $91(65)$ & $10(11)$ & 6 \\
& 5 & 106 & $66(62)$ & $4(6)$ & 4 \\
& 6 & 149 & $108(72)$ & $19(18)$ & $18(17)$ \\
Total & 7 & 95 & $77(81)$ & $8(10)$ & $5(6)$ \\
& & 854 & $548(64)$ & $58(11)$ & $56(10)$ \\
\hline
\end{tabular}

Female Swiss albino mice made pseudopregnant by mating with vasectomized males were used as recipients. When vaginal plugs were found in the morning, transfer operations were performed in the afternoon. The eggs that had cleaved into two cells in culture after fertilization in vitro or in vivo were transferred into the ampullar portion of the left oviduct according to the method described by Tarkowski (1959). Each recipient received ten eggs and was killed on the 17th day after transfer in order to examine the uterine contents.

It can be seen from Table 1 that $71 \%$ of the eggs fertilized in vivo cleaved after culture for $24 \mathrm{hr}$ and $64 \%$ of eggs cleaved following insemination with epididymal spermatozoa and futher culturing for $24 \mathrm{hr}$. Following the transfer of 180 eggs fertilized in vivo into the oviducts of eighteen recipient mice and eighty eggs fertilized in vitro into the oviducts of eight recipient mice, twentynine normal fetuses $(16 \%$, from six pregnant mice) and ten $(13 \%$, from two pregnant mice), respectively, were obtained. Thus, there was very little difference in the proportion of development in culture (Table 1) or following 
transfer between the eggs fertilized in vivo and those fertilized by epididymal spermatozoa in vitro under our experimental conditions.

Mukherjee \& Cohen (1970) reported that $37 \%$ of mouse eggs fertilized in vitro by uterine spermatozoa could develop into blastocysts in culture. We found that only $10 \%$ of the eggs fertilized in vitro by epididymal spermatozoa could develop into blastocysts in culture even though we used the same medium. In the transfer of eggs fertilized in vitro, Whittingham (1968) obtained a $20 \%$ development, Cross \& Brinster (1970) observed a 3.2\% development, and we obtained a 13 to $16 \%$ development when two-cell eggs were transferred into the oviduct. Mukherjee \& Cohen (1970), however, obtained a $48 \%$ development when eggs which had been fertilized in vitro and cultured to the blastocyst stage were transferred. Thus, it appears that the great variation obtained by different investigators is due to the diversity of procedures and techniques. There is no doubt, however, that the normal development of mouse eggs fertilized in vitro by epididymal spermatozoa is possible, although the potential for development still awaits further improvement.

This work was supported by grants from the U.S. Public Health Service (HD 03472) and the Ford Foundation. Thanks are due to Mrs Rose Bartke for assistance.

\section{REFERENCES}

CRoss, P. G. \& BRinster, R. L. (1970) In vitro development of mouse oocytes. Biol. Reprod. 3, 298.

Iwamatsu, T. \& Chang, M. C. (1969) In vitro fertilization of mouse eggs in the presence of bovine follicular fluid. Nature, Lond. 224, 919.

Inamatsu, T. \& Chang, M. C. (1970) Further investigation of capacitation of sperm and fertilization of mouse eggs in vitro. F. exp. Zool. 175, 271.

Inamatsu, T. \& Chang, M. C. (1971) Factors involved in the fertilization of mouse eggs in vitro. J. Reprod. Fert. 26, 197.

MukherJee, A. B. \& Cohen, M. M. (1970) Development of normal mice by in vitro fertilization. Nature, Lond. 228, 472.

TARKowski, A. K. (1959) Experiments on the transplantation of ova in mice. Acta theriol. 2, 251.

Toyoda, Y., Yokoyama, M. \& Hosi, T. (1971) Studies on the fertilization of mouse eggs in vitro. I. In vitro fertilization of eggs by fresh epididymal sperm. Jap. F. Anim. Reprod. 16, 147.

WhItTen, W. K. \& Biggers, J. D. (1968) Complete development in vitro of the pre-implantation stages of the mouse in a simple chemically defined medium. F. Reprod. Fert. 17, 399.

Whitringham, D.G. (1968) Fertilization of mouse eggs in vitro. Nature, Lond. 220, 592. 